\title{
Influence of Amino Acids on the Secondary Somatic Embryogenesis Proliferation Process of Moroccan Cork Oak (Quercus suber L.)
}

\author{
Naouar Ben Ali*, Lamarti Ahmad \\ Plant Biotechnology Laboratory, Department of Biology, Faculty of Sciences of Tetouan, Abdelmalek Essaadi University, Tetouan, \\ Morocco \\ Email: ^benalinaouar@yahoo.fr
}

How to cite this paper: Ben Ali, N. and Ahmad, L. (2021) Influence of Amino Acids on the Secondary Somatic Embryogenesis Proliferation Process of Moroccan Cork Oak (Quercus suber L.). American Journal of Plant Sciences, 12, 603-613.

https://doi.org/10.4236/ajps.2021.124040

Received: March 4, 2021

Accepted: April 19, 2021

Published: April 22, 2021

Copyright $\odot 2021$ by author(s) and Scientific Research Publishing Inc. This work is licensed under the Creative Commons Attribution International License (CC BY 4.0).

http://creativecommons.org/licenses/by/4.0/

\section{(c) (i) Open Access}

\begin{abstract}
The present study aims to explore the regeneration potential of Moroccan cork oak through the secondary somatic embryogenesis process. Particularly, we focus on the analysis of amino acids influence on the quantity and quality of the regenerated secondary embryos. The amino acids tested are: Glutamine, asparagine, arginine, tryptophane, methionine, casein hydrolysate and urea. Each amino acid is added in the Margara $(\mathrm{N} 30 \mathrm{~K})$ medium at different concentrations ranged between 10 and $500 \mathrm{mg} / \mathrm{l}$. The results are collected after 2 months of culture. First analysis shows that the glutamine and the casein hydrolysate gives a maximum number of somatic embryos, clusters and pre-embryos newly formed on the clusters. By comparison to the control medium, the increase of the secondary embryos number directly formed exceed $36 \%$ in the case of casein hydrolysate and $35 \%$ of in the case of glutamine both at the concentration of $30 \mathrm{mg} / \mathrm{l}$. However, the test of the combination of these amino acids did not have any significant results. In terms of quality, the influence of amino acids on the morphology of secondary embryos was analyzed.
\end{abstract}

\section{Keywords}

Quercus suber L., Secondary Embryos, Amino Acids, Glutamine, Asparagine, Casein Hydrolysat

\section{Introduction}

Cork oak (Quercus suber L.) is considered one of the most important multipurpose species in all the Mediterranean area due to its ecological value as an environmental protector. Seed production and cork-derived industries have a major economic input into the maintenance of rural populations [1]. In the Moroccan 
cork oak forest ecosystem, the economic interest of this species has facilitated the development of new strategies for reforestation programs [2]. However, conventional breeding of cork oak is constrained by its long reproductive cycle, which includes long juvenile phase, and its complex reproductive biology, including self-incompatibility and a high degree of heterozygosis [3].

However, cloning of adult trees is still difficult, and in some species it is only possible at a juvenile phase because in most woody species, the selection of elite trees is only possible at the adult phase when individuals show their characteristics [4] [5].

The propagation through somatic embryogenesis (SE) is considered to be an important tool for obtaining efficient true to-type vegetative propagation of selected mature trees [6]. Within the genus Quercus, SE induction from mature trees has been reported in many Quercus species like: holm oak [7] cork oak [5], [8], and pedunculate oak [9] [10] [11]. These studies were specifically focused on the embryos multiplication and conversion into plantlets, generally considered to be the most problematical stages limiting the use of SE for mass propagation, due to the low frequency of response [12].

The secondary somatic embryogenesis (SE) is a phenomenon where by new somatic embryos are initiated from other somatic embryos. Some cultures are able to retain their competence for secondary SE for many years, and thus provide useful material for various studies, as described for Vitis rupestris [13], cork oak (Quercus suber) [4]. Additionally, for some species, primary SE is less efficient than secondary SE, as reported for cork oak [5] [14]. Therefore, in plants with long life cycles, such as dicotyledonous woody plants, preserving embryogenic lines can be a cost-effective maintenance while those lines are being tested in field [15].

One of the most influential factors in the morphogenic response associated with secondary embryos culture is the kind and concentration of growth regulators. Amino acids serve as primary sources of organic nitrogen for the growth of many cells. They additionally promote communication between cells and tissues within multicellular organisms [16]. Organic nitrogen nutrition was also reported to affect somatic embryogenesis in conifers [7]. They have generally been used in the different phases of conifer somatic embryogenesis [17]. Glutamine and other aminoacids, can improve cell proliferation as well as regeneration in specific genotypes [18] [19] [20] [21].

In this context, the objective of the present work is to study the effect of different sources, levels and balances of nitrogen on both induction and development of secondary SE from mature somatic embryos of Moroccan cork oak (Quercus suber L.).

Our work has been also devoted to study for the first time the secondary somatic embryogenesis process of Moroccan cork oak Quercus suber L. The objective was to explore the embryogenic potential through the secondary somatic embryogenesis process. This process is considered as an effective means for the mass propagation and maintenance of somatic embryos for micropropagation and 
its application to Moroccan cork oak. Mainly, we focus on the influence of amino acids on proliferation secondary somatic embryos.

\section{Material and Methods}

Mature embryos at the cotyledonal stage, of about $8-10 \mathrm{~mm}$ in size and approximate fresh weight of about $60 \mathrm{mg}$ from somatic origin, were cultured in 9 $\mathrm{cm}$ diameter Petri dishes containing $20 \mathrm{ml}$ of proliferation medium (N30K) and supplemented with different amino acids: glutamine (Gln), arginine (Arg), asparagine (Asn), méthionine (Met), tryptophan (Try), urea (Urea) and casein hydrolysate $(\mathrm{CH})$ or a mixture of the All amino acids combinations. The experiment was arranged in a completely randomized design with 28 treatments. All cultures were maintained in a constant ambient temperature of $25^{\circ} \mathrm{C} \pm 2{ }^{\circ} \mathrm{C}$ in darkness.

For this experiment, 30 explants somatic embryos were cultured per experimental unit in each of the 28 treatments (the control and seven amino acid treatments). All the somatic embryos were homogeneously distributed between treatments. The experiment was repeated three times, thus a total of $840 \mathrm{em}$ bryos was used.

Percentage of explants with secondary SE and number of viable clusters and somatic embryos on clusters per explants (primary somatic embryo) were recorded after 8 weeks in culture. The resulting data were submitted to a statistical package SPSS 17.0. [22]. One-way analysis of variance (ANOVA) was carried out to determine the differences between the treatments that produced cotyledonal somatic embryos. Multiple comparisons were made using Duncans post-hoc test $(\mathrm{a}=0.05)$.

\section{Results and Discussions}

The effect of amino acids concentration on ES proliferation is shown in Table 1. The control medium is used as reference state. The results are collected after 8 weeks from the initiation of the culture and are presented in terms of average number of SSE formed per primary embryos, average number of clusters per primary embryos and average number of SSE newly formed on clusters.

In general, amino acids show a quite acceptable embryogenic response will compared to the control medium. A visual examination of secondary somatic embryos formed in the presence of Glu or HC shows a translucent aspect with normal morphology. Figure 1 illustrates some examples of embryos morphology obtained in the presence of amino acids. The increase in the number of secondary embryos exceeds $36 \%$ and $35 \%$ respectively in the case of casein hydrolyzate and glutamine respectively at the concentration of $30 \mathrm{mg} / \mathrm{l}$ (Figure 2).

The response of the secondary somatic embryogenesis process differs depending on the type of amino acid used. The highest proliferation ratio of secondary somatic embryos (SSE) was obtained with the $30 \mathrm{mg} / \mathrm{l}$ of glutamine and $30 \mathrm{mg} / \mathrm{l}$ of $\mathrm{CH}$ respectively at $6.16 \pm 0.48$ and $6.2 \pm 0.62$ respectively (Table 1 ). In 


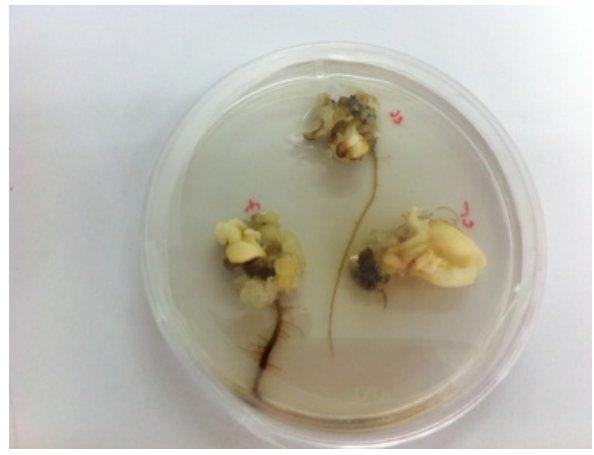

(a)

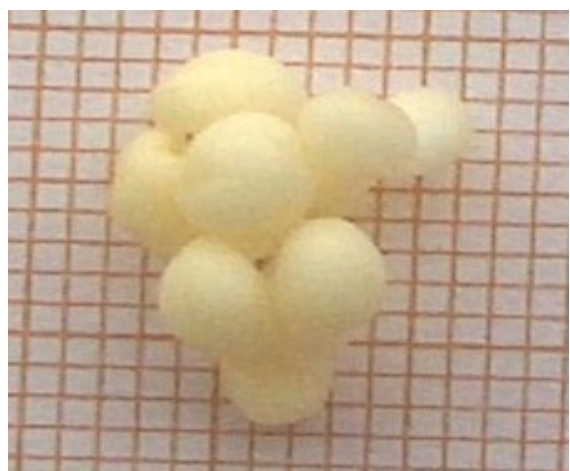

(a)

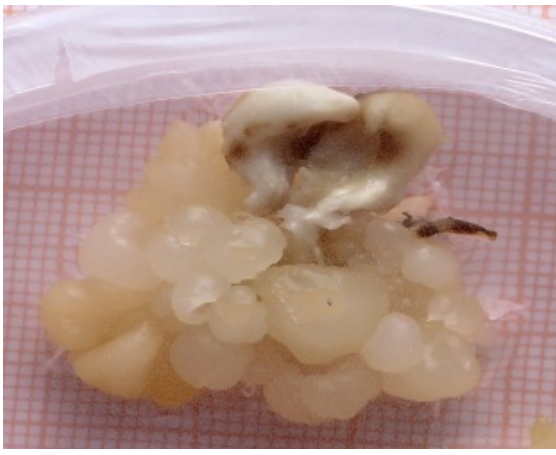

(b)

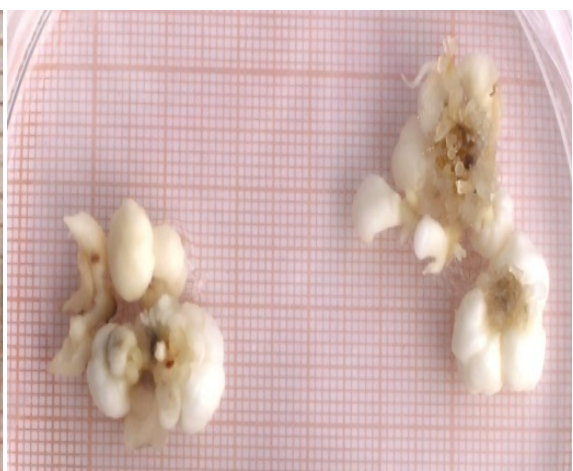

(b)

Figure 1. Influence of amino acids on the induction of secondary somatic embryogenesis after 2 months of culture: (a) Regeneration of secondary somatic embryos (SSE) on the control medium; (b) Secondary embryos have a translucent appearance during development; (c) Structure and size of secondary somatic embryos isolated after two months of growth; (d) Effect of Glu at high concentration.

Table 1. Effect of treatment with different concentrations of amino acids on the secondary somatic embryogenesis process of Moroccan Quercus suber L.

\begin{tabular}{|c|c|c|c|c|}
\hline amino acid & $\begin{array}{l}\text { Concentration } \\
(\mathrm{mg} / \mathrm{L})\end{array}$ & $\begin{array}{l}\text { Average number of } \\
\text { SSE per primary SE }\end{array}$ & $\begin{array}{c}\text { Average number } \\
\text { of clusters per primary SE }\end{array}$ & $\begin{array}{l}\text { Average number } \\
\text { of SSE per cluster }\end{array}$ \\
\hline \multirow[t]{2}{*}{ Control medium } & 0 & $4.53 \pm 0.57$ abcde & $0.6 \pm 0.11 \mathrm{a}$ & $1.73 \pm 0.39 \mathrm{abc}$ \\
\hline & 10 & $4.63 \pm 0.78$ abcde & $0.6 \pm 0.12 \mathrm{a}$ & $1.63 \pm 0.43 \mathrm{abcd}$ \\
\hline \multirow[t]{3}{*}{ Glutamine } & 30 & $6.16 \pm 0.48 \mathrm{ab}$ & $0.6 \pm 0.11 \mathrm{a}$ & $1.9 \pm 0.83 \mathrm{ab}$ \\
\hline & 500 & $5.26 \pm 0.75 \mathrm{abc}$ & $0.6 \pm 0.13 \mathrm{a}$ & $1.67 \pm 0.35 \mathrm{abcd}$ \\
\hline & 10 & $3.93 \pm 0.51 \mathrm{cde}$ & $0.5 \pm 0.11 \mathrm{ab}$ & $1.23 \pm 0.34$ bcdefg \\
\hline \multirow[t]{3}{*}{ Asparagine } & 30 & $5.13 \pm 0.63 \mathrm{abcd}$ & $0.5 \pm 0.09 \mathrm{ab}$ & $1.53 \pm 0.33$ abcdef \\
\hline & 500 & $5.3 \pm 0.62 \mathrm{abc}$ & $0.36 \pm 0.10 \mathrm{abcd}$ & $1.16 \pm 0.36$ bcdefg \\
\hline & 10 & $3.46 \pm 0.55 \mathrm{cdef}$ & $0.36 \pm 0.10 \mathrm{abcd}$ & $0.76 \pm 0.24$ cdefg \\
\hline \multirow[t]{3}{*}{ Arginine } & 30 & $3.97 \pm 0.66 \mathrm{cde}$ & $0.26 \pm 0.08 \mathrm{bcd}$ & $0.7 \pm 0.24$ cdefg \\
\hline & 500 & $3.47 \pm 0.63 \mathrm{cdef}$ & $0.3 \pm 0.08 \mathrm{abcd}$ & $0.8 \pm 0.26$ cdefg \\
\hline & 10 & $3.6 \pm 0.51 \mathrm{cde}$ & $0.06 \pm 0.04 \mathrm{~d}$ & $0.2 \pm 0.13 \mathrm{f}$ \\
\hline \multirow[t]{2}{*}{ Methionine } & 30 & $3.6 \pm 0.52 \mathrm{cde}$ & $0.23 \pm 0.07 \mathrm{bcd}$ & $0.5 \pm 0.18$ ef \\
\hline & 500 & $1.83 \pm 0.31 \mathrm{fg}$ & $0.26 \pm 0.08 \mathrm{bcd}$ & $0.4 \pm 0.13 \mathrm{f}$ \\
\hline
\end{tabular}


Continued

\begin{tabular}{|c|c|c|c|c|}
\hline & 10 & $4.26 \pm 0.52 \mathrm{cde}$ & $0.23 \pm 0.07 \mathrm{bcd}$ & $0.57 \pm 0.23$ ef \\
\hline \multirow[t]{3}{*}{ Tryptophan } & 30 & $4.46 \pm 0.62$ abcde & $0.53 \pm 0.09 \mathrm{ab}$ & $1.5 \pm 0.31$ abcde \\
\hline & 500 & $0.4 \pm 0.21 \mathrm{~g}$ & $0.13 \pm 0.06 \mathrm{~cd}$ & $0.26 \pm 0.17 \mathrm{f}$ \\
\hline & 10 & $5.00 \pm 0.64 \mathrm{abcd}$ & $0.26 \pm 0.08 \mathrm{bcd}$ & $0.63 \pm 0.22 \mathrm{def}$ \\
\hline \multirow[t]{3}{*}{ Urea } & 30 & $5.33 \pm 0.54 \mathrm{abc}$ & $0.4 \pm 0.09 \mathrm{ab}$ & $1.00 \pm 0.25$ bcdef \\
\hline & 500 & $3.06 \pm 0.44$ ef & $0.3 \pm 0.08 \mathrm{abcd}$ & $0.8 \pm 0.23 \mathrm{cdef}$ \\
\hline & 10 & $4.67 \pm 0.64$ abcde & $0.33 \pm 0.08 \mathrm{abcd}$ & $0.93 \pm 0.26 \mathrm{bcdef}$ \\
\hline \multirow[t]{2}{*}{ Casein Hydrolysat } & 30 & $6.2 \pm 0.62 \mathrm{a}$ & $0.5 \pm 0.10 \mathrm{ab}$ & $2.23 \pm 0.51 \mathrm{a}$ \\
\hline & 500 & $4.00 \pm 0.45 \mathrm{cde}$ & $0.29 \pm 0.07 \mathrm{abcd}$ & $1.61 \pm 1.12 \mathrm{ef}$ \\
\hline
\end{tabular}

Data were recorded after 8 weeks of culture, values are mean \pm SE for three repeated experiments, each with three replicate Petri dishes and 3 embryogenic explants per plate. Within each embryogenic line and column, values with the same letter were not significantly different at $\mathrm{P} \leq 0.05$ (LSD test).
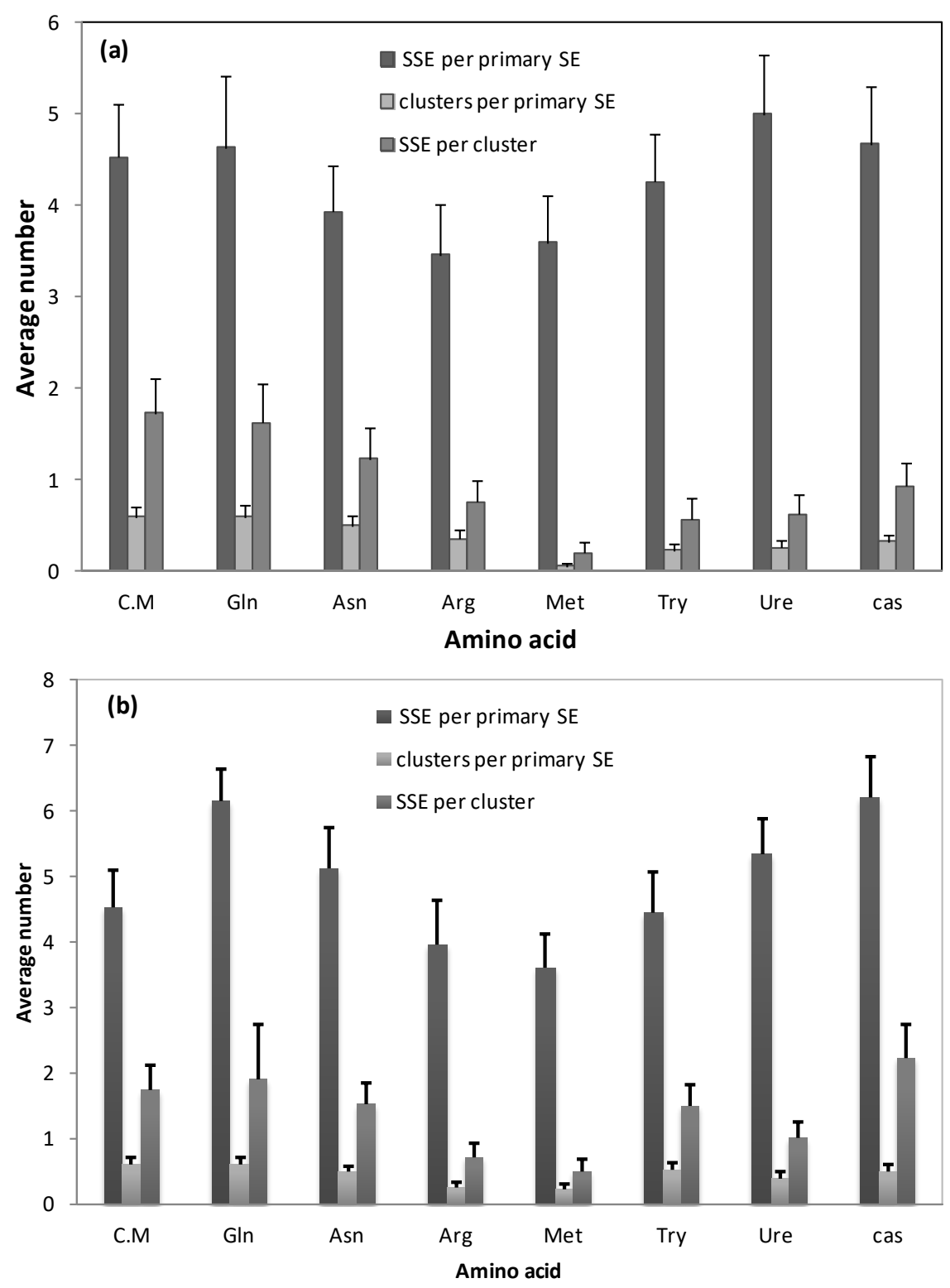


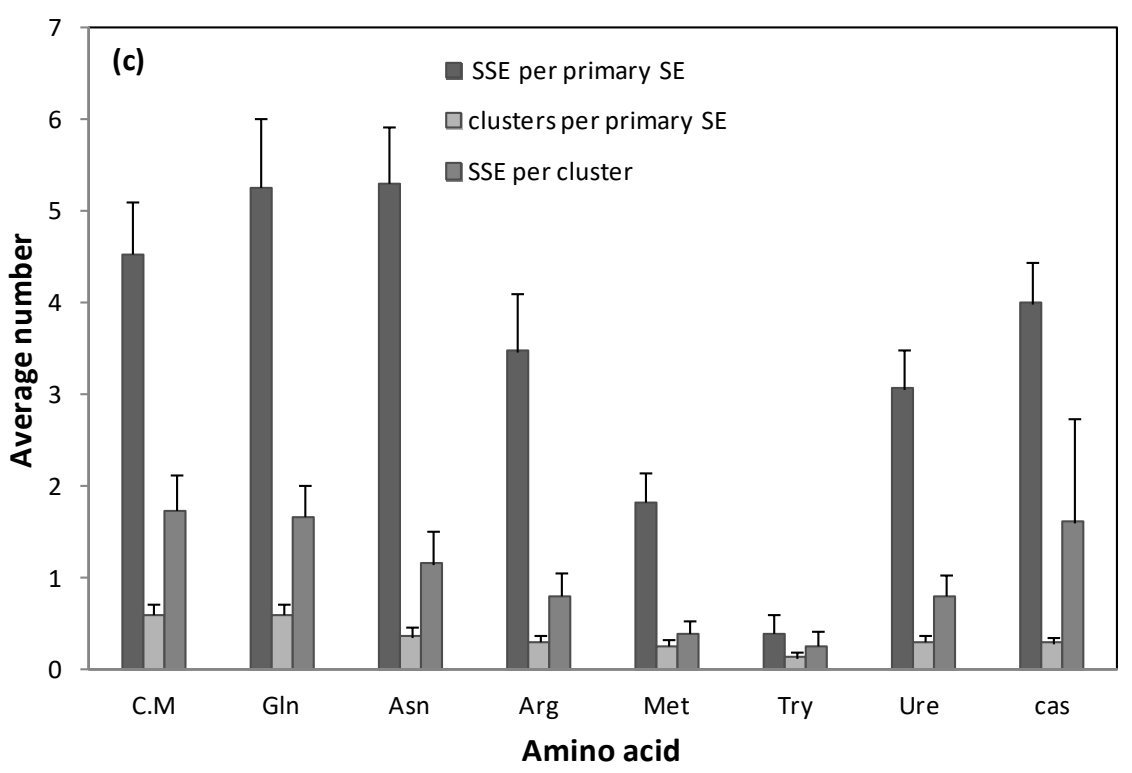

Figure 2. Effect of treatment with different concentrations of amino acids on the secondary somatic embryogenesis process of Moroccan Quercus suber L: (a) At concentration of $10 \mathrm{mg} / \mathrm{l}$; (b) At concentration of $30 \mathrm{mg} / \mathrm{l}$; (c) At concentration of $500 \mathrm{mg} / \mathrm{l}$.

addition, clusters and secondary somatic embryos formed on the clusters had a similar proliferation ratio $(0.6 \pm 0.11$ and $1.63 \pm 0.83$ respectively for clusters and SSE on clusters with Glu; $0.5 \pm 0.10$ and $1.67 \pm 0.35$ respectively for clusters and SSE on clusters with $\mathrm{CH}$. It should be noted that the Glutamine is assimilated more rapidly into carbon skeletons of proteins than other inorganic nitrogen sources, and it is known to be an important amino acid in somatic embryogenesis of other species [18].

However, a lower proliferation ratio was obtained on the culture medium containing metheonine with a number of SSE that can not exceed $3.6 \pm 0.52$ followed by the arginine significant difference and the results remain in general quite acceptable.

On the other hand, results shows that the combinations of the different type of amino acid have not been satisfactory and the results remain without significance even if it exceeds sometimes the ratio of proliferation obtained in the case of the control medium (Table 2). In certain cases, we can observe that the induction of secondary somatic embryogenesis decrease significantly when the proliferation medium was supplemented with the combination of the aminoacids $(0.9 \pm 0.18)$ (Figure 3$)$.

The reported results show that the amino acids in general promote the multiplication and growth of embryos; this may be explained by the fact that these amino acids replace partially the NH4. Furthermore, they increase the levels of reduced nitrogen which stimulates the development of somatic embryos. Usually, the best embryogenic response can be obtained when the amino acids are added to the proliferation medium at moderated concentration $(30 \mathrm{mg} / \mathrm{l})$.

Embryo growth is a critical step for the development in vitro and germination 
Table 2. Effect of combination of different amino acids on the secondary somatic embryogenesis process of Moroccan Quercus suber L.

\begin{tabular}{|c|c|c|c|c|}
\hline Combination of amino acid & Concentration (mg/L) & $\begin{array}{l}\text { Average number } \\
\text { of SSE per primary SE }\end{array}$ & $\begin{array}{l}\text { Average number } \\
\text { of clusters per primary SE }\end{array}$ & $\begin{array}{l}\text { Average number } \\
\text { of SSE per cluster }\end{array}$ \\
\hline Control medium & 0 & $4.53 \pm 0.57$ abcde & $0.6 \pm 0.11 \mathrm{a}$ & $1.73 \pm 0.39 \mathrm{abc}$ \\
\hline COMB1: & $10+10+10$ & $3.33 \pm 0.42 \mathrm{def}$ & $0.36 \pm 0.11 \mathrm{abcd}$ & $1.46 \pm 0.51 \mathrm{abcde}$ \\
\hline Glutamine + Asparagine + & $30+30+30$ & $3.63 \pm 0.39 \mathrm{cde}$ & $0.23 \pm 0.07 \mathrm{bcd}$ & $0.57 \pm 0.22 \mathrm{ef}$ \\
\hline COMB2: & $10+10+10+10+10$ & $4.43 \pm 0.39$ abcde & $0.6 \pm 0.09 \mathrm{a}$ & $1.53 \pm 0.28$ abcde \\
\hline $\begin{array}{c}\text { Glutamine + Asparagine + } \\
\text { Arginine + Methionine + }\end{array}$ & $30+30+30+30+30$ & $5.00 \pm 0.46 \mathrm{abcd}$ & $0.4 \pm 0.09 \mathrm{abc}$ & $1.06 \pm 0.28 \mathrm{bcdef}$ \\
\hline Tryptophan & $500+500+500+500+500$ & $0.9 \pm 0.18 \mathrm{~g}$ & $0.4 \pm 0.09 \mathrm{abc}$ & $0.9 \pm 0.25$ bcdef \\
\hline
\end{tabular}

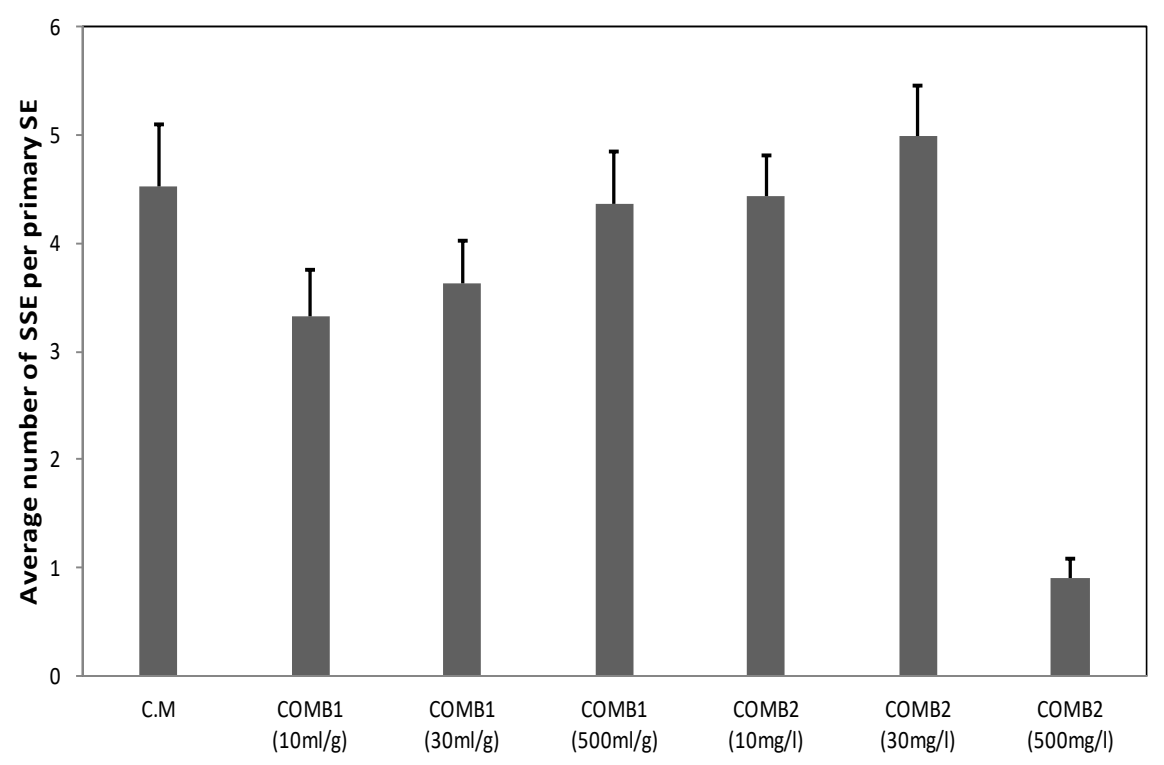

Figure 3. Effect of combination of different amino acids on the secondary somatic embryogenesis process of Moroccan Quercus suber L. CM: control medium, COMB1: Glutamine + Asparagine + Arginine, COMB2: Glutamine + Asparagine + Arginine + Méthionine + Tryptophane

of somatic embryos [22] [23]. In this work, it is noted that the Amino acids activate the regeneration of the embryos. However, the need for amino acids in the culture medium depends also on the species; the explant or on the desired morphogenic response. Nevertheless, in some cases growth inhibition has been reported [7] [24] [25]. Merkle et al. [26] reported that the addition of amino acids to the culture medium might inhibit or promote the SE development and conversion. Von Arnold [27] found a strong negative effect of L-glutamine, L-arginine, and L-asparagine on induction of somatic embryogenesis in P. abies. Kirby et al. [28] reported that the addition of $\mathrm{CH}$ inhibited growth in cell suspension of Picea menziesii [19]. Smith [29] [30] supplemented the maturation medium of Pinus radiata with a solution of seven amino acids, to improve somatic embryos production and plantlet recovery, and reported significant effects on somatic em- 
bryogenesis. In other plant species, such as Picea glauca, some amino acids had either a negative or no effect on somatic embryo maturation [31] [32].

Furthermore, our experiments show that the embryogenic response depends also on the type and the nature of the amino acid used. As illustrated in Figure 2 the arginine and the metheonine show some kind of inhibition against the proliferation of somatic embryos. Consequently, the poor response obtained in the case of the amino acids combination can be attributed in some measure to the presence of the arginine and the metheonine.

\section{Conclusions}

The obtained results showed that amino acids tend to favor the multiplication and growth of embryos, embryogenic response was quite acceptable. Compared to the control medium, secondary embryos increased beyond $36 \%$ in the case of casein hydrolyzate and $35 \%$ glutamine at a concentration of $30 \mathrm{mg} / \mathrm{l}$. The lower rate of proliferation is obtained in the case of methionine followed by arginine, both show some kind of inhibition against the proliferation of somatic embryos.

However, tests on the combination of amino acids did not give satisfaction and results remain without significance. The establishment of histological study of secondary ultratsuctural cell and comparison batwing the content of amino acids and others plant hormones may improve the efficiency of Moroccan cork oak micropropagation.

\section{Fund}

This research was partially funded by Hassan II Academy of Science and Technology (Morocco) through project named "vegetative propagation of Moroccan cork oak with the technique of somatic embryogenesis".

\section{Conflicts of Interest}

The authors declare no conflicts of interest regarding the publication of this paper.

\section{References}

[1] Gomez, A., Manzanera, J.A. and Pintos, B. (2014) Embryogenesis in Oak Species. A Review. Forest Systems, 23, 191-198. https://doi.org/10.5424/fs/2014232-05829

[2] Aafi, A., Achhal El Kadmiri, A., Benabid, A. and Rouchdi, M. (2005) Richesse et diversité floristique de la subéraie de la Mamora (Maroc). Acta Botanica Malacitana, 30, 127-138. https://doi.org/10.24310/abm.v30i0.7187

[3] Pérez, M., Bueno, M.A., Escalona, M., Toorop, P., Rodrıguez, R. and Canal, M.J. (2013) Temporary Immersion Systems (RITA@) for the Improvement of Cork Oak Somatic Embryogenic Culture Proliferation and Somatic Embryo Production. Trees 27, 1277-1284. https://doi.org/10.1007/s00468-013-0876-y

[4] Hernandez, I., Celestino, C., Alegro, J. and Toribio, M. (2003) Vegetative Propagation of Quercus suber L. by Somatic Embryogenesis: II. Plant Regeneration from Selected Cork Oak Trees. Plant Cell Reports, 21, 765-770. 
https://doi.org/10.1007/s00299-003-0604-y

[5] Hernández, S.I. (2007) Regeneración clonal de alcornoques adultos (Quercus suber L.) mediante embriogénesis somática. Tesis de doctoral, 1-241.

[6] Capote, T., Usié, A., Barbosa, P., Ramos, M., Morais-Cecilio, L. and Goncalves, S. (2019) Transcriptome Dynamics of Corc Oak (Quercus suber) Somatic Embryogenesis Reveals Active Gene Players in Transcription Regulation and Phytohormone Homeostasis of Embryo Development. Tree Genetics \& Genomes, 15, 52. https://doi.org/10.1007/s11295-019-1353-6

[7] Martinez, M.T., San José, M.C., Vieitez, A.M., Cernadas, M.J. and Ballester, A. (2017) Prpagation of Mature Quercus ilex L. (Holm Oak) Trees by Somatic Embryogenesis. Plant Cell, Tissue and Organ Culture, 131, 321-333. https://doi.org/10.1007/s11240-017-1286-4

[8] Hernandez, I., Cuenca, B., Carneros, E., Alonso-Blazquez, N., Ruiz, M., Celestino, C., Ocana, L., Alegre, J. and Toribio, M. (2011) Application of Plant Regeneration of Selected Cork Oak Trees by Somatic Embryogenesis to Implement Multivarietal Forestry for Cork Production. Tree and Forestry Science and Biotechnology, 5, 19-26.

[9] Toribio, M., Fernandez, C., Celestino, C., Martinez, M.T., San-Jose, M.C. and Vieitez, A.M. (2004) Somatic Embryogenesis in Mature Quercus robur Trees. Plant Cell, Tissue and Organ Culture, 76, 283-287. https://doi.org/10.1023/B:TICU.0000009245.92828.26

[10] Valladares, S., Sánchez, C., Martínez, M.T., Ballester, A. and Vieitez, A.M. (2006) Plant Regeneration through Somatic Embryogenesis from Tissues of Mature Oak Trees: True-to-Type Conformity of Plantlets by RAPD Analysis. Plant Cell Reports, 25, 879-886. https://doi.org/10.1007/s00299-005-0108-Z

[11] San-José, M.C., Corredoira, E., Martinez, M.T., Vidal, N., Valladares, S., Mallon, R., Vieitez, A.M. (2010) Shoot Apex Explants for Induction of Somatic Embryogenesis in Mature Quercus robur L. Trees. Plant Cell Reports, 29, 661-671. https://doi.org/10.1007/s00299-010-0852-6

[12] Mallon, R., Covelo, P. and Vieitez, A.M. (2011) Improving Secondary Embryogenesis in Quercus robur. Application of Temporary Immersion for Mass Propagation. Trees, 26, 731-741. https://doi.org/10.1007/s00468-011-0639-6

[13] Martinelli, L., Candioli, E., Costa, D. and Poletti, V. (2001) Morphogenic Competence of Vitis rupestris S. Secondary Somatic Embryos with a Long Culture History. Plant Cell Reports, 20, 279-284. https://doi.org/10.1007/s002990100339

[14] Pinto, G., Valentim, H., Costa, A., Castro, S. and Santos, C. (2002) Somatic Embryogenesis and Plant Regeneration from Leaf Calli of Mature Quercus suber L. Plants. In Vitro Cellular \& Developmental Biology_Plant, 6, 569-572. https://doi.org/10.1079/IVP2002352

[15] Pinto, G., Park, Y.S., Silva, S., Neves, L., Araujo, C. and Santos, C. (2008) Factors Affecting Maintenance, Proliferation, and Germination of Secondary Somatic Embryos of Eucalyptus globulus Labill. Plant Cell, Tissue Organ Culture, 95, 69-78. https://doi.org/10.1007/s11240-008-9417-6

[16] Young, B.G., Jack, D.L., Smith, D.W. and Saier, J.M.H. (1999) The Amino Acid/ Auxin: Proton Symport Permease Family. Biochimica et Biophysica Acta, 1415, 306-322. https://doi.org/10.1016/S0005-2736(98)00196-5

[17] Garin, E., Bernier-Cardou, M., Isabel, N., Klimaszewska, K. and Plourde, A. (2000) Effect of Sugars, Amino Acids, and Culture Technique on Maturation of Somatic Embryos of Pinus strobus on Medium with Two Gellan Gum Concentrations. Plant Cell, Tissue and Organ Culture, 62, 27-37. 
https://doi.org/10.1023/A:1006402215457

[18] Corredoira, E., Valladares, S., Vieitez, A.M. and Ballester, A. (2008) Improved Germination of Somatic Embryos and Plant Recovery of European Chestnut. In Vitro Cellular \& Developmental Biology - Plant, 44, 307-315.

https://doi.org/10.1007/s11627-008-9105-6

[19] Kim, Y.W., Newton, R., Frampton, J. and Han, K.-H. (2008) Embryogenic Tissue Initiation and Somatic Embryogenesis in Fraser Fir (Abies fraseir (Pursh) Poir.). In Vitro Cellular \& Developmental Biology_Plant, 45, 400-406. https://doi.org/10.1007/s11627-008-9169-3

[20] Martínez, M.T., Corredoira, E., Valladares, S., Jorquera, L. and Vieitez, A.M. (2008) Germination and Conversion of Somatic Embryos Derived from Mature Quercus robur Trees: The Effects of Cold Storage and Thidiazuron. Plant Cell, Tissue and Organ Culture, 95, 341-351. https://doi.org/10.1007/s11240-008-9448-Z

[21] Corredoira, E., Toribio, M. and Vieitez, E. (2014) Clonal Propagation via Somatic Embryogenesis in Quercus spp. In: Ramawhat, K.G., Mérillon, J.M. and Ahuja, M.R., Eds., Tree Biotechnology, CRC Press, Boca Raton, 262-302.

[22] SPSS for Windows (2010) Guia Breve de IBM SPSS Statistics 19.SPSS Inc. IBM Company, Chicago, 171.

[23] Pintos, B., Manzanera, J.A. and Bueno, M.A. (2010) Oak Somatic and Gametic Embryos Maturation Is Affected by Charcoal and Specific Amino Acids Mixture. Annals of Forest Science, 67, 205. https://doi.org/10.1051/forest/2009098

[24] Fridborg, G. and Eriksson, T. (1975) Effects of Activated Charcoal on Growth and Morphogenesis in Cell Cultures. Physiologia Plantarum, 34, 306-308. https://doi.org/10.1111/j.1399-3054.1975.tb03843.x

[25] Fridborg, G., Pedersen, L., Landstrom, E. and Eriksson, T. (1978) The Effect of Activated Charcoal on Tissue Cultures: Adsorption of Metabolites Inhibiting Morphogenesis. Physiologia Plantarum, 43, 104-106. https://doi.org/10.1111/j.1399-3054.1978.tb01575.x

[26] Merkle, S.A. (1995) Strategies for Dealing with Limitations of Somatic Embryogenesis in Hardwood Trees. Plant Tissue Culture Biotechnology, 1, 112-121.

[27] Von Arnold, S. (1987) Improved Efficiency of Somatic Embryogenesis in Mature Embryos of Picea abies (L.) Karst. Journal of Plant Physiology, 128, 233-244. https://doi.org/10.1016/S0176-1617(87)80237-7

[28] Kirby, E.G., Leustek, T. and Lee, M.S. (1987) Nitrogen Nutrition. In: Bonga, J.M. and Durzan, D.J., Eds., General Principles and Biotechnology, Cell and Tissue Culture in Forestry, Vol. 1, Nijhoff, Dordrecht, 67-88. https://doi.org/10.1007/978-94-017-0994-1 5

[29] Smith, D.R. (1994) Growth Medium for Plant Embryogenic Tissue. Australia Canada Patent \#PM5232.

[30] Smith, D.R. (1997) The Role of in Vitro Methods in Pine Plantation Establishment: The Lesson from New Zealand. Plant Tissue Culture and Biotechnology, 3, 63-73.

[31] Stuart, D.A., Nelsen, J., MC Call, C.M., Strickland, S. and Walker, K.A. (1985) Physiology of the Development of Somatic Embryos in Cell Cultures of Alfalfa and Celery. In: Zaitlin, M., Day, P. and Hollaender, A., Eds., Bio-Technology in Plant Science, Academic Press, New York, 35-47. https://doi.org/10.1016/B978-0-12-775310-2.50009-0

[32] Barrett, J.D., Park, Y.S. and Bonga, J.M. (1997) The Effectiveness of Various Nitrogen Sources in White Spruce [Picea glauca (Moench) Voss] Somatic Embryogenesis. Plant Cell Reports, 16, 411-415. https://doi.org/10.1007/s002990050250 


\section{Abbreviations}

Arg-L-arginine;

Asn-L-asparagine;

$\mathrm{CH}-$ Casein hydrolyzate;

Cl-Clusters;

Gln-L-glutamine;

Met-Methionine;

SE-Somatic embryos, somatic embryogenesis;

SSE-Secondary somatic embryos, secondary somatic embryogenesis;

Try-Tryptophan. 